Gut, 1985, 26, 902-906

\title{
Intravenous omeprazole rapidly raises intragastric $\mathrm{pH}$
}

\author{
R P WALT, J R REYNOLDS, M J S LANGMAN, H L SMART, \\ G KITCHINGMAN, K W SOMERVILLE, AND C J HAWKEY \\ From the Department of Therapeutics, University Hospital, Nottingham, and Department of Surgery, \\ University Hospital, Nottingham
}

SUMMARY Twenty four hour intragastric acidity was measured in five duodenal ulcer patients studied at least three times. The effects of different dosage regimens of intravenous omeprazole was compared with placebo. Mean intragastric acidity from 1000 to 0800 was $34 \cdot 3 \pm 4.3 \mathrm{mmol} / \mathrm{l}$ on placebo. After omeprazole $80 \mathrm{mg}$ at 0900 and $40 \mathrm{mg}$ at 1700 mean acidity was $2 \cdot 1 \pm 0.9 \mathrm{mmol} / \mathrm{l}$ and after omeprazole $80 \mathrm{mg}$ at 0900 and $80 \mathrm{mg}$ at 1700 it was $0.7 \pm 0.2 \mathrm{mmol} / \mathrm{l}$. pH remained above $4 \cdot 0$ for about $80 \%$ of recordings with these regimens and for only $5 \%$ with placebo. Three of the five patients also received omeprazole $80 \mathrm{mg}$ at $0900,40 \mathrm{mg}$ at 1700 and $40 \mathrm{mg}$ at 0100 when $\mathrm{pH}$ remained above 4.0 for $90 \%$ of recordings with $99 \%$ inhibition of acidity. Omeprazole rapidly raised intragastric $\mathrm{pH}$ in all patients and maintained a gastric $\mathrm{pH}$ of $>4.0$ for most of the time. Large doses of IV omeprazole were required compared with studies using the oral compound.

Omeprazole is the first of a new group of antisecretory agents to be studied extensively in humans. The substituted benzimidazoles inhibit the proton pump of the parietal cell which exchanges hydrogen for potassium ions. ${ }^{1-3}$ Omeprazole is a potent and long lasting inhibitor of basal secretion, pentagastrin and histamine stimulated secretion and 24 hour acidity in man. ${ }^{4-6}$ It raises median 24 hour intragastric $\mathrm{pH}$ of duodenal ulcer patients from $1.4-5.3$ after seven single daily doses of $30 \mathrm{mg}$ taken by mouth. ${ }^{6}$ The effect of oral omeprazole is cumulative over three-four days after which time a plateau effect is achieved. ${ }^{7}$

The antisecretory effect of oral omeprazole is much greater than that due to $\mathrm{H}_{2}$ blockers ${ }^{6}$ and therefore clinical efficacy may be improved. Intravenous antisecretory drugs are frequently used in the treatment of upper gastrointestinal bleeding, and in the prevention of stress ulceration and the acid aspiration syndrome during anaesthesia. There are no reports of the effect of intravenous omeprazole on intragastric acidity. The aim of this study was to investigate the effect of different intravenous regimens of omeprazole on 24 hour intragastric acidity in duodenal ulcer patients.

Address for correspondence: Dr R P Walt, Department of Therapeutics. University Hospital, Queen's Medical Centre, Nottingham NG7 2UH.

Received for publication 21 September 1984.

\section{Methods}

PATIENTS

Five men with previously diagnosed duodenal ulceration were studied whilst in symptomatic remission. Antisecretory agents were not allowed for two weeks before the start and during the series of experiments. The mean and range of ages and weights of the patients were 37.4 years (range 28-56) and $72 \mathrm{~kg}$ (range 65-81). They were all non-smokers. Written informed consent was obtained from each patient and the study was approved by the local ethical committee.

All five patients underwent the first three studies and three patients took part in a fourth. The experimental design was similar to that previously described with modifications made for intravenous administration. ${ }^{6}$ The patients were admitted at 0730 on Saturday mornings to an empty hospital 'day ward', having fasted from midnight. The dietary and environmental conditions were identical on each day. The patients were allowed up to $50 \mathrm{ml}$ of tap water to help the passage of a $10 \mathrm{FG}$ nasogastric tube (Argyle Medical). The first aspirate of gastric contents was therefore mainly saliva and water and was ignored in the analysis of results. Five to 10 millilitre samples of gastric contents were aspirated at half hourly intervals until 1300 and thereafter each hour on the hour until 0800 the next 902 
electrode (Corning) and digital $\mathrm{pH}$ meter (Corning 130) to two decimal places. The $\mathrm{pH}$ meter was calibrated between readings with buffers of $\mathrm{pH} 1.09$, $4 \cdot 01$, and 7.00. The patients stayed on their beds and remained fasted until $1300 \mathrm{~h}$ when lunch was served. The menu and timing of subsequent meals and snacks was always identical. No other food or drink was taken.

As part of a separate study to assess the efficacy of continuous radiotelemetric $\mathrm{pH}$ monitoring, ${ }^{9}$ two of the subjects also swallowed a radiotelemetric capsule which was tethered by a fine nylon string to the cheek.

Omeprazole was supplied coded for the randomisation as powder in separate vials with diluent (Polyethylene glycol [PEG]) and was made up within an hour of injection. Lyophilised omeprazole sodium has a shelf life of 12 months at $25^{\circ} \mathrm{C}$. When reconstituted in PEG it remains stable for four hours. The injection is not stable in other fluids. Each injection was of $20 \mathrm{ml}$ irrespective of the dose of omeprazole. Placebo (sodium chloride) was supplied in identical vials. The $20 \mathrm{ml}$ injections were infused through electrical pumps (Vickers) at a rate of $99.9 \mathrm{ml} / \mathrm{h}$ giving an infusion time of approximately 12 minutes. The dose and timing of the infusions is shown in the Table. The first three studies were double blind and randomised so that it was impossible to tell if any particular infusion was of placebo or active drug. In the fourth study, however, all subjects received three doses of omeprazole. The doses used were chosen because preliminary data suggested that $80 \mathrm{mg}$ of IV omeprazole caused intragastric $\mathrm{pH}$ to rise above 4.0 and to remain there for up to eight hours. The choice of the second (and third) doses was empirical.

Intravenous butterfly or venflon cannulae were used for injections and blood sampling. The cannulae were kept patent with heparinised saline. Venous blood was taken for plasma omeprazole estimation at lengthening intervals after the first injection until 7 h 50 min (just before the next injection). Safety studies comprising a clinical ex-

Table The timing and dosage of infusions of omeprazole or placebo for the four studies.

\begin{tabular}{lllll}
\hline Study & Dose & \multicolumn{2}{c}{ Timing } \\
\hline A & Placebo & 0900, & 1700 & \\
B & $80 \mathrm{mg}$ & 0900 & & \\
& $40 \mathrm{mg}$ & & 1700 & \\
C & $80 \mathrm{mg}$ & 0900 & & \\
& $80 \mathrm{mg}$ & & 1700 & \\
D & $80 \mathrm{mg}$ & 0900 & & \\
& $40 \mathrm{mg}$ & & 1700 & 0100 \\
\hline
\end{tabular}

amination, ECG, full blood count and biochemical screen were done before and after the series of experiments. The studies were separated by at least two weeks.

ANALYSIS OF RESULTS

Hourly $\mathrm{pH}$ measurements taken on the hour from 1000 have been included in the analysis so that the half hourly measurements in the morning do not unduly weight the general assessment of the results. Hydrogen ion activity during omeprazole was compared with placebo by analysis of variance.

\section{Results}

The studies were well tolerated and no side effects were noted or reported by the patients. One patient had a minimally raised alkaline phosphatase level before the studies which remained raised throughout. Two measurements of serum creatinine were outside the normal range during the study and returned to normal. Two problems were encountered with gastric aspiration. The nasogastric tube moved so that the tip lay in the oesophagus overnight in one patient. This went unnoticed because adequate aspirates (of saliva and mucus) were obtained and was only discovered in the morning when the length of tube was measured. In a second patient the nasogastric tube curled up in the oesophagus (radiograph screening) and had to be replaced. In both cases a radiotelemetric device was adequately functioning and the hourly recordings from this intragastric electrode have been used for the 11 missing $\mathrm{pH}$ values.

The effect of the two twice daily intravenous regimens on mean hourly intragastric acidity in all five patients is shown in Fig. 1. The distribution of $\mathrm{pH}$ measurements during these three studies is shown in Fig. 2, for the recordings between $1000-$ that is, one hour after injection, and 0800 . Mean intragastric acidity during this period fell from $34.3 \pm 4.3 \mathrm{mmol} / 1$ to $2 \cdot 1 \pm 0.9 \mathrm{mmol} / 1(80 \mathrm{mg} / 40 \mathrm{mg}$ omeprazole $-94 \% \mathrm{p}<0.001)$ and to $0.7 \pm 0.2 \mathrm{mmol} / \mathrm{l}$ $(80 \mathrm{mg} / 80 \mathrm{mg}$ omeprazole $-98 \% \mathrm{p}<-0.001)$. Acidity decreased in all patients within one hour of the start of the infusion of omeprazole. Indeed, by 1000 $\mathrm{h}$ the lowest $\mathrm{pH}$ recorded was $4 \cdot 0$. Two individuals' acidity decreased to a $\mathrm{pH}>4.0$ throughout the studies with omeprazole whilst in the remainder there were occasional values below $2 \cdot 0(6 \%)$.

The effect of the three dose schedule on mean hourly intragastric acidity in the three patients studied is shown in Fig. 3. The distribution of $\mathrm{pH}$ measurements in these patients is shown in Fig. 4. Mean intragastric acidity (1000-0800 fell from $36 \cdot 3 \pm 5 \cdot 3 \mathrm{mmol} / 1$ to $3 \cdot 3 \pm 1 \cdot 7 \mathrm{mmol} / 1(80 \mathrm{mg} / 40 \mathrm{mg}$ 


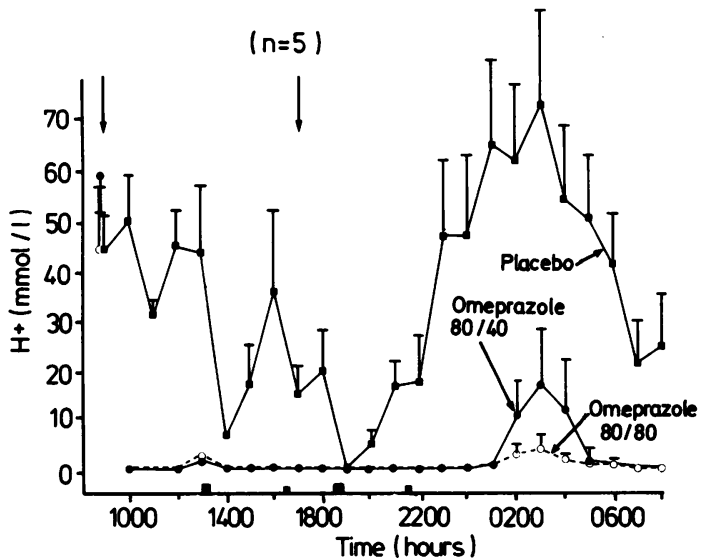

Fig. 1 Mean hourly intragastric acidity $\pm S E M$. Standard meals as shown by black boxes. Infusions were given at the times indicated by the vertical arrows.

omeprazole $-91 \% \mathrm{p}<0.001)$, to $1 \cdot 1 \pm 0.4 \mathrm{mmol} / 1(80$ $\mathrm{mg} / 80 \mathrm{mg}$ omeprazole $-97 \% \mathrm{p}<0.001)$ and to $0.5 \pm 0.4 \mathrm{mmol} / \mathrm{l}(80 \mathrm{mg} / 40 \mathrm{mg} / 40 \mathrm{mg}$ omeprazole-99\% p $<0.001)$.

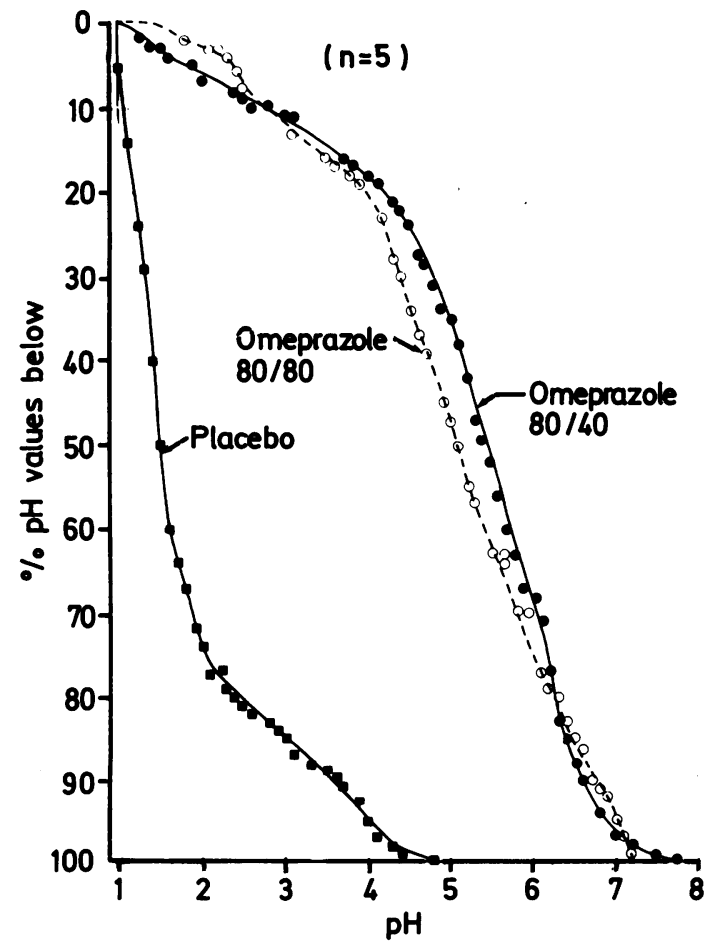

Fig. 2 Frequency distribution of $\mathrm{pH}$ measurements. Percentage $\mathrm{pH}$ measurements observed below a given $\mathrm{pH}$ after placebo or two regimens of intravenous omeprazole.

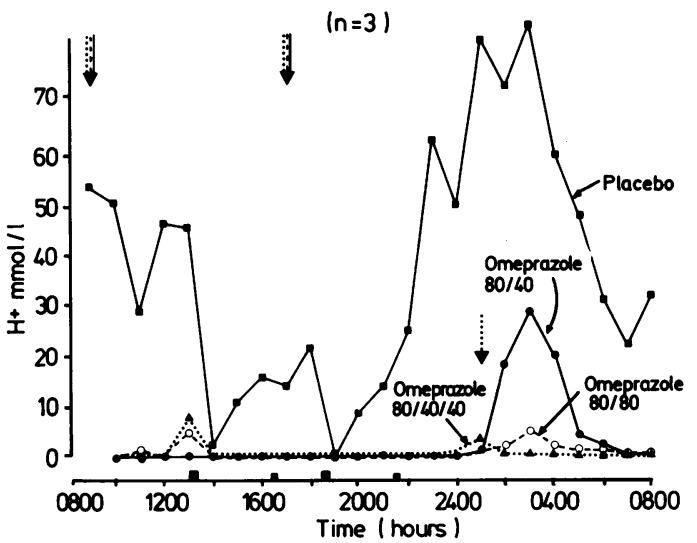

Fig. 3 Mean hourly intragastric acidity. Standard meals shown as black boxes. Infusions were given at the times indicated by the vertical arrows.

\section{PLASMA OMEPRAZOLE CONCENTRATIONS}

During placebo experiments, omeprazole was not detected in any patient. Omeprazole concentrations rose to a peak in all patients soon after the end of

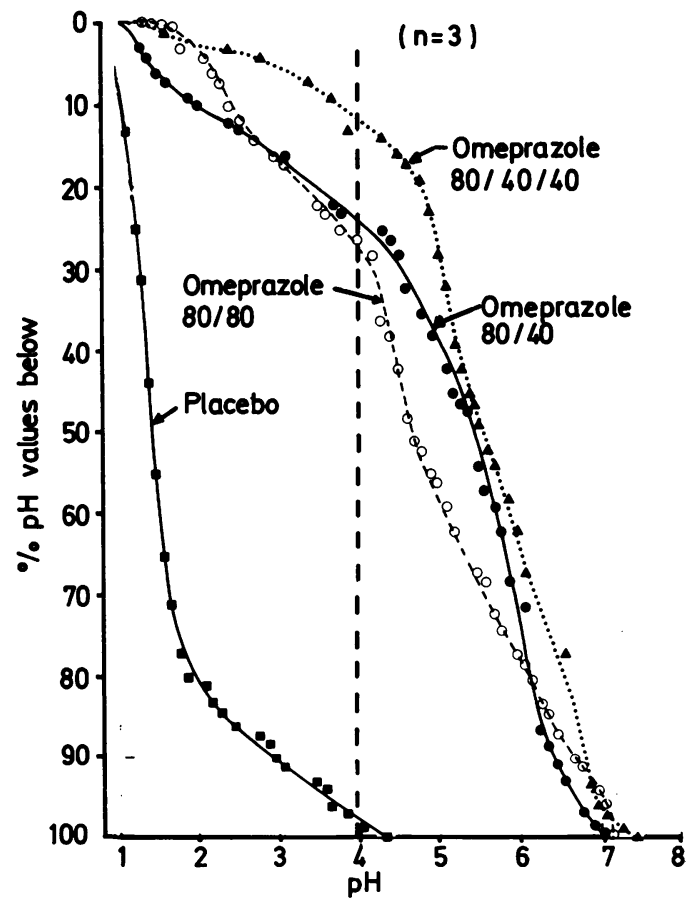

Fig. 4 Frequency distribution of $\mathrm{pH}$ measurements. Percentage pH measurements observed below a given $p H$ after placebo or three regimens of intravenous omeprazole. 
the injection of $80 \mathrm{mg}$ (Fig. 5). Individual differences were small and by $7 \mathrm{~h} 50 \mathrm{~min}$ after injections the drug was not detectable in plasma.

\section{Discussion}

Intravenous omeprazole produced a rapid and potent inhibition of intragastric acidity in all patients. The duration of this effect was shorter than expected from the data obtained during oral treatment. ${ }^{6}{ }^{10}$ There was marked interindividual variation in response: the 'worst' response was from the oldest patient who had an intragastric $\mathrm{pH}$ of $<2 \cdot 0$ for four hours at night even after omeprazole 80/40, by contrast another patient had only a single $\mathrm{pH}$ measurement $<4.0$ with all three omeprazole dosage regimens. Although the total dose of omeprazole remained constant, two patients with nocturnal acidity $(\mathrm{pH}<3.0)$ had improved responses when the drug was given as three rather than two doses. The inability of histamine $\mathrm{H}_{2}$-receptor antagonists to inhibit nocturnal acidity in some patients has been reported and remains unexplained. ${ }^{11}$ It was possible that in such patients vagal stimulation overnight resulted in continued acidity despite $\mathrm{H}_{2}$-receptor blockade. Omeprazole would have been expected to have completely inhibited even vagal stimulation of gastric secretion.

The intravenous compound was less effective than expected. Daily oral doses of omeprazole $30 \mathrm{mg}$ decrease 24 hour intragastric acidity of duodenal ulcer patients by $97 \%{ }^{610}$ whereas we have found that similar inhibition of acidity requires $160 \mathrm{mg}$ of omeprazole when given intravenously. Oral studies with omeprazole have largely been carried out after repeated dosing, however, whereas this experiment

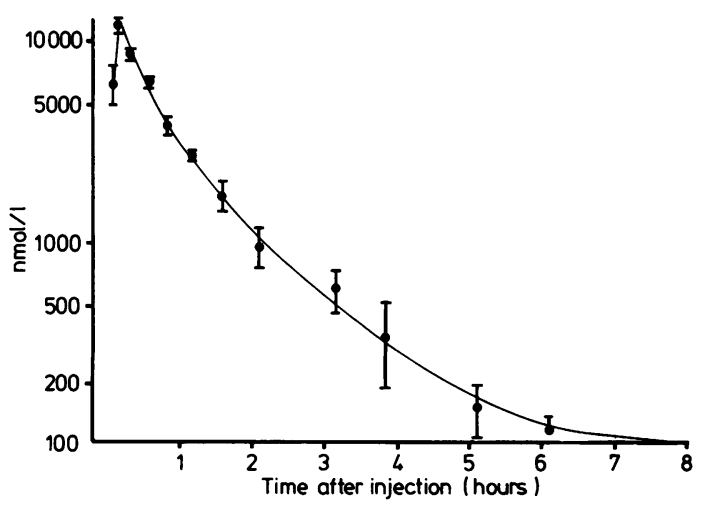

Fig. 5 Mean plasma omeprazole levels. Mean \pm SEM plasma omeprazole concentrations in five patients on two occasions given $80 \mathrm{mg}$ omeprazole intravenously. determined gastric acidity during the first treatment day. Oral omeprazole has a cumulative effect and if this feature of the drug's action is shared by the intravenous compound, greater inhibition may be achieved with lower or fewer doses on the second and third days of parenteral treatment.

Although single oral doses of $80 \mathrm{mg}$ of omeprazole were reported to cause a decrease of 24 hour acidity of $95 \% .^{12}$ The apparent difference in responses to oral and intravenous omeprazole suggests either that the drug may have a local effect in the stomach before absorption or that an active metabolite is formed in the GI tract. Oral therapy may thus be generally prefereable except when parenteral dosing is more practical, for instance in patients with prominent symptoms of vomiting.

Our aim was to assess an appropriate starting dose of intravenous omeprazole for clinical use. It is clear that two doses of omeprazole $(80 \mathrm{mg} / 80 \mathrm{mg}$ ) will raise the intragastric $\mathrm{pH}$ of duodenal ulcer patients to $>4.0$ within a hour of administration but will not always maintain $\mathrm{pH}$ at about that level for the subsequent 22 hours. Increasing the frequency of administration does seem to increase the duration of drug action but might be clinically less manageable because of the need for frequent injections and because, at least at present, the drug has to be prepared freshly by dissolution in polyethylene glycol. Nevertheless, intravenous omeprazole given eight hourly in the dose $80 \mathrm{mg} / 40 \mathrm{mg} / 40 \mathrm{mg}$ causes intragastric $\mathrm{pH}$ to rise rapidly to a concentration which is believed to be important for protection from stress ulceration for most of 24 hours. This regimen is appropriate for the first day of treatment in clinical trials.

We are grateful to Sister Everitt and her staff for the use of the day ward and to Drs H J Baddeley, R G Long, A Seward, and G Scott for skilled technical help. We acknowledge the financial support of Astra Pharmaceuticals and A Howe for the supplies of omeprazole.

\section{References}

1 Sachs G, Chang HH, Rabon E, Schackman R, Lewin M, Saccomani G. A non-electrogenic $\mathrm{H}^{+}$pump in plasma membranes of hog stomach. J Biol Chem 1976; 251: 7690-8.

2 Fellenius E, Berglindh T, Sachs G et al. Substituted benzimidazoles inhibit acid secretion by blocking $\left(\mathrm{H}^{+} \mathrm{K}^{+}\right)$ATPase. Nature 1981; 290: 150-61.

3 Wallmark B, Sachs G, Mardh S, Fellenius E. Inhibition 
of gastric $\mathrm{H}^{+} \mathrm{K}^{+}$ATPase by the substituted benzimidazole picoprazole. Biochem Biophys Acta 1983; 728: 31-8.

4 Olbe L, Haglund U, Leth R et al. Effects of substituted benzimidazole (H149/94) on gastric acid secretion in humans. Gastroenterology 1982; 83: 193-8.

5 Lind T, Cederberg C, Ekenved G, Haglund U, Olbe L. Effect of omeprazole - a gastric proton pump inhibitor - on pentagastrin stimulated acid secretion in man. Gut 1983; 24: 170-6.

6 Walt RP, Gomes M, Wood EC, Logan LH, Pounder RE. Effect of daily omeprazole on 24 hour intragastric acidity. Br Med J 1983; 287: 12-4.

7 Howden CW, Forrest JAH, Reid JL. The effects of omeprazole on gastric secretion in man. [Abstract]. Clin Sci 1983; 64: 71A.

8 Pounder RE, Williams JG, Milton-Thompson GJ, Misiewicz JJ. 24 hour control of intragastric acidity by cimetidine in duodenal ulcer patients. Lancet 1975; 2: 1069-72.

9 Reynolds J, Walt RP, Smart H, Langman MJS. Radiotelemetric measurement of twenty four hour intragastric $\mathrm{pH}$ in duodenal ulcer patients. [Abstract] Gut 1984; 25: A1152.

10 Sharma BK, Walt RP, Pounder RE, Gomes M, Wood EC, Logan LH. Optimal dose of oral omeprazole for maximal 24 hour decrease of intragastric acidity. Gut 1984; 25: 957-64.

11 Gledhill T, Hunt RH. Studies of intragastric acidity and nocturnal acid secretion in cimetidine nonresponders. Gastroenterology 1982; 24: 1060.

12 Naesdal J, Bodemar G, Walan A. Effect of omeprazole on 24-hour gastric acidity in patients with peptic ulcer disease. A comparison of single doses followed by 1 weeks treatment. Scand J Gastroenterol 1983; 18: suppl 86: 55 . 